\title{
THE EFFECT OF A NEW NITRO-ASPIRIN ON APOPTOSIS OF NEUTROPHIL GRANULOCYTES
}

\author{
VASILEV S****, VUČEVIĆ DRAGANA*, GAŠIĆ SONJA*, MAJSTOROVIĆ IVANA*, VASILIJIĆ S*, \\ ĆUPIĆ $\mathrm{V} * *$ and ČOLIĆ $\mathrm{M}^{*}$ \\ *Military Medical Academy, Institute for Medical Research, Belgrade, Serbia \\ ** University of Belgrade, Faculty of Veterinary Medicine, Serbia \\ ${ }^{\star * *}$ Institute for the Application of Nuclear Energy - INEP, Belgrade, Serbia
}

(Received 1. March 2008))

Apoptosis of neutrophil granulocytes is a critical event in the resolution of inflammation. Neutrophils have a short lifespan which can be modulated by aspirin. In this work we studied the effect of a nitroaspirin (NCX4040) on apoptosis of inflammatory granulocytes. This nitro-aspirin has been synthesized in attempt to reduce the side effects of aspirin in the gastrointestinal tract. Inflammatory granulocytes have been isolated from polyvinyl sponges implanted under the skin of Albino Oxford (AO) rats. Inflammatory cells that were isolated 20 hours later were about $95 \%$ neutrophil granulocytes. The cells were cultivated $24 \mathrm{~h}$ with different concentrations of NCX4040 ranging from $0.01 \mu \mathrm{M}$ to $10 \mu \mathrm{M}$. After that period, apoptosis of neutrophils was performed by using morphological criteria, as well as by flow cytometry (after staining the cells with propidium iodide). We found that NCX4040 at concentrations from 0.25 to $10 \mu \mathrm{M}$ induced the apoptosis of rat inflammatory granulocytes in a dose-dependent manner. Also, in these concentrations NCX4040 decreased production of nitric oxide in the cells culture supernatants. In conclusion, our results suggest that antiinflammatory properties of NO-aspirins are additionally potentiated by their proapoptotic effect on granulocytes, which could be a novel mechanism of their action.

Key words: nitro-aspirin, neutrophil granulocytes, apoptosis

\section{INTRODUCTION}

Aspirin and other Non-Steroidal Anti-Inflammatory Drugs (NSAIDs) as side effect have ulcerations of gastrointestinal mucosa and bleeding (Varagić et al., 1996; Awatry 2000). Nitric oxide (NO) donors effectively reduce the damage of the gastric mucosa (Elliott et al., 1995) and aid the healing process after such damage. Observation that patients who simultaneously received aspirin and NO donors did not have any side effects related to the gastrointestinal tract, turned the development of NSAIDs to a new direction. As a result of these efforts, new NSAIDs, capable of releasing the biological mediator and gastroprotective agent 


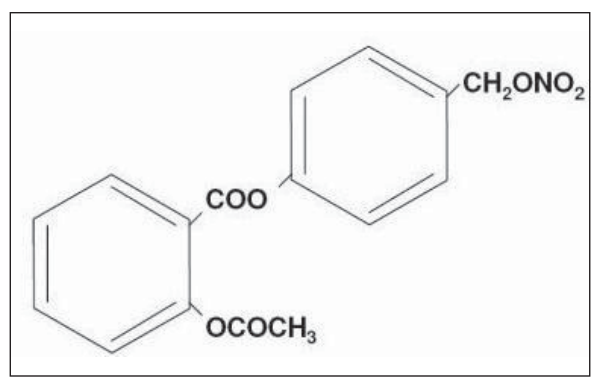

Figure 1. The chemical structure of NCX4040

nitric oxide, have been synthesized (Bandarage and Janero, 2001). One among them is NCX4040, a nitro derivative of aspirin (Figure 1).

Neutrophils are very important cells involved in host defence against microorganisms. They are the first leukocytes which migrate to the inflammation site, a few hours before other cells (Girard, 2003; Witko-Sarsat et al., 2000). Neutrophil granulocytes have the shortest lifespan, among leukocytes (12-48 h), which can be modulated by cytokines, pharmacological agents and xenobiotics (Maianski et al., 2004).

Apoptosis plays an important role in development, in tissue homeostasis and in the defence against viral infection and mutation. This process is regulated by complex molecular signaling systems (Dlamini et al., 2004; Guimaraes and Linden, 2004). Apoptosis of neutrophil granulocytes is important for the resolution of inflammation (Kam and Ferch, 2000), since failure to undergo this form of cell death leads to increased tissue damage and exacerbation of the inflammatory response. Manipulation of the rate of apoptosis in inflammatory neutrophils could be of therapeutic benefit.

The effect of NCX4040 on the apoptosis of inflammatory granulocytes has not been studied before, and therefore was the subject of this study.

\section{MATERIALS AND METHODS}

\section{Animals}

Male 10 weeks old Albino Oxford (AO) rats, weighing 200-220 g, bred at the Institute for Medical Research, Military Medical Academy (MMA), Belgrade, were used in all experiments. The rats were fed standard laboratory chow (Veterinarski zavod Subotica) and tap water ad libitum. All experimental procedures on animals were conducted in adherence to the NIH guidelines for the use of experimental animals, with the approval of the Ethical Committee of MMA.

\section{Neutrophil collection}

Effects of NCX4040 on the apoptosis of inflammatory neutrophil granulocytes were studied using a model of inflammation by implanting sterile polyvinyl sponges under the skin of rats as described in our previous work (Vasilev et al., 2006). Briefly, rats were anaesthetized and small incisions were made in the skin of their back, creating subcutaneous pockets. Sterile polyvinyl sponges were implanted subcutaneously and pushed down under the skin. After 20 hours, the rats were killed, the sponges were retrieved aseptically and infiltrated cells from the sponges were collected. Cells were counted in a standard 
hematocytometer chamber. Inflammatory cells that were isolated were about 95\% neutrophil granulocytes. Viability of neutrophils was about $98 \%$.

\section{Cultivation of the cells}

Neutrophil granulocutes were plated in 96-well plates $\left(5 \times 10^{5}\right.$ cells/well, $200 \mu \mathrm{L})$ along with increasing concentrations $(0.01-10 \mu \mathrm{M})$ of NCX4040 (NicOx, France) and cultivated for $24 \mathrm{~h}$. The control consisted of cells cultivated in complete RPMI 1640 medium. Culture supernatants were collected after $24 \mathrm{~h}$ and used for the measurement of nitric oxide production. The cells were used for the detection of apoptosis.

\section{Measurement of apoptosis}

For the measurement of apoptosis, two different methods were used. Analysis using morphological criteria (chromatin condensation, nuclear pyknosis or nuclear fragmentation) was performed after fixation and staining of cells with Türk reagent using light microscopy. Apoptosis was also detected by staining hypodiploid nuclei using propidium iodide (PI) (Migita et al., 1994). After incubation, neutrophils were washed once with phosphate buffered saline (PBS) and resuspended in $0.4 \mathrm{~mL}$ solution with $20 \mu \mathrm{L}$ of $\mathrm{PI}(1 \mu \mathrm{g} / \mathrm{ml})$. Analyses were performed on an EPICS XL-MLC cytofluorometer (Coulter, Germany).

\section{Measurement of NO production}

Production of NO, quantified by the accumulation of nitrite in the $24 \mathrm{~h}$ culture medium, was measured spectrophotometrically using the Griess reaction with sodium nitrite as a standard (Green et al., 1982). Culture supernatants (50 $\mu \mathrm{L})$ were mixed with equal volumes of $1 \%$ sulphanilamide (Sigma Chemicals Co., St Louis, Mo., USA) in $5 \% \mathrm{H}_{3} \mathrm{PO}_{4}$ and $0.1 \% \mathrm{~N}$-1-naphthylethylene diamine dihydrochloride (Sigma Chemicals Co., St Louis, Mo., USA) in distilled water, and after 10 minutes at room temperature the absorbance, was measured at $570 \mathrm{~nm}$ with $650 \mathrm{~nm}$ reference wavelength

Statistical analysis

All data are expressed as mean \pm standard deviation. Each test was performed at least three times. Statistical analysis was performed by Student's ttest, using the PC Program. A p value less than 0.05 were considered significant.

\section{RESULTS}

\section{Effect of NCX4040 on the Apoptosis of Rat Neutrophil Granulocytes}

After a 24 hour incubation of neutrophils isolated from sponges with different concentrations of NCX4040 at $37^{\circ} \mathrm{C}$, apoptosis was determined by morphological method. It was found that NCX4040, at concentrations from $0.01 \mu \mathrm{M}$ to $0.175 \mu \mathrm{M}$, did not influence on the spontaneous apoptosis of these cells. However, at the concentrations from 0.25 to $10 \mu \mathrm{M}, \mathrm{NCX} 4040$ induced in the same cells a statistically significant degree of apoptosis in a dose-dependent 
manner (Figure 2). Results were confirmed by flow cytometry analysis after staining the cells with propidium iodide (Figure 3 ).

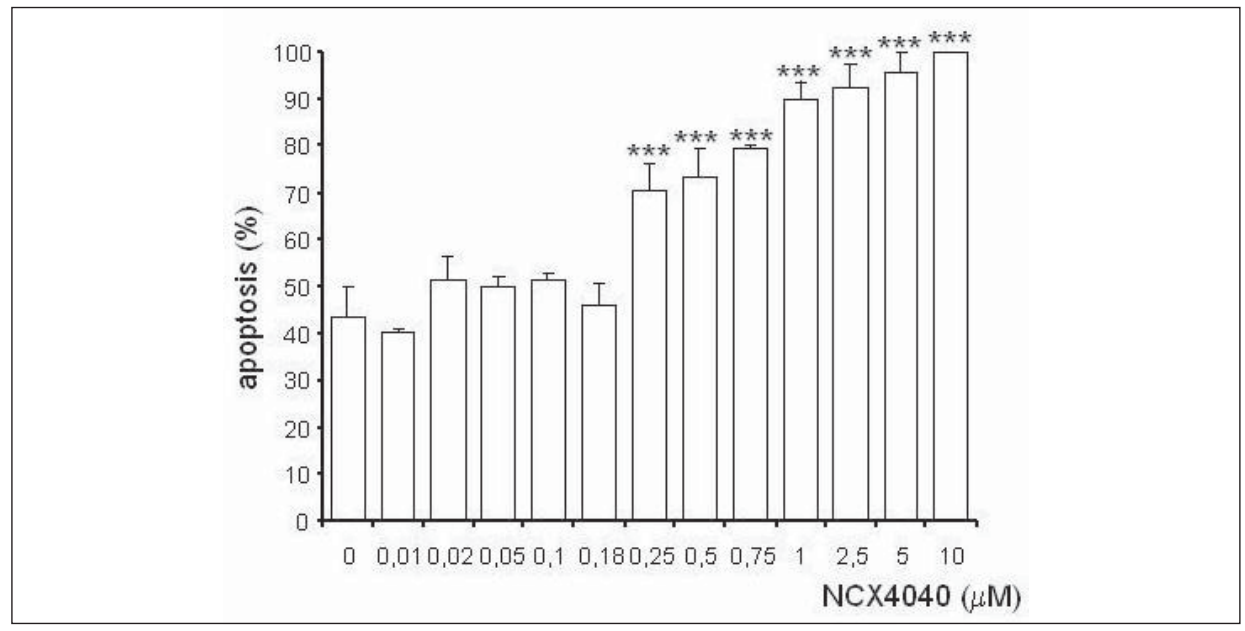

Figure 2. The effect of NCX4040 on apoptosis of neutrophil granulocytes in culture. Apoptosis was measured after staining the cells with Türk reagent and analysis by light microscopy, using morphological criteria as described in Materials and Methods. Values are given as mean \pm SD of triplicates from one representative experiment, out of several ones with similar results. Results of morphological analysis are given on the basis of 500 counted cells in each native preparation (*** $\mathrm{p}<0.001$ compared to control)

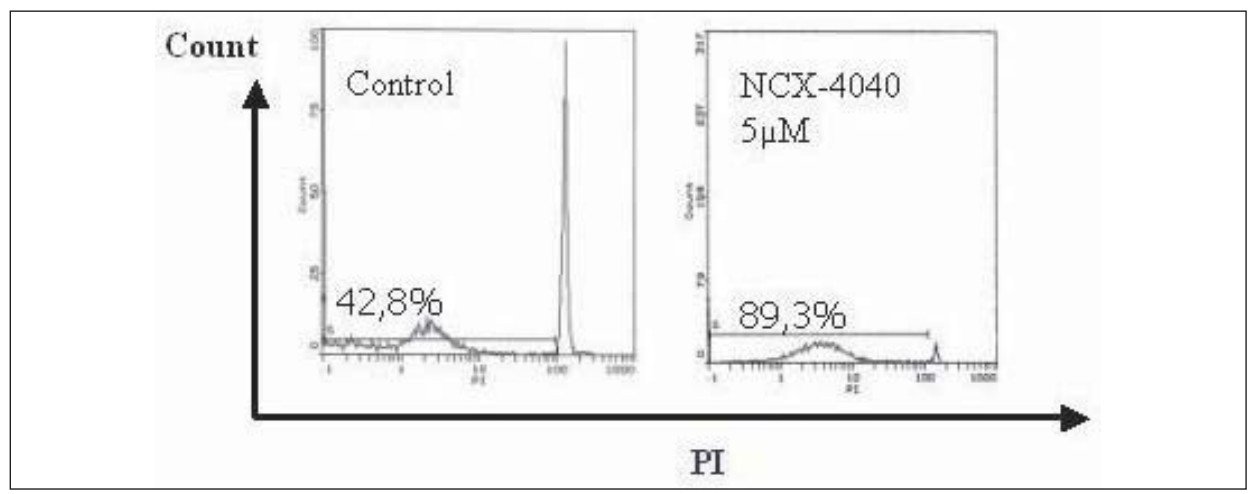

Figure 3. The effect of NCX4040 on apoptosis of neutrophil granulocytes in culture. Apoptosis was measured after staining the cells with propidium iodide using cytofluorometry as described in Materials and Methods. The number above the horizontal line shows the percentage of hypodiploid nuclei 


\section{Effect of NCX4040 on NO Production}

We found that in concentration higher than $0.25 \mu \mathrm{M}$ NCX4040 caused a statistically significant, dose-dependent decrease of NO production (as assessed by the quantity of nitrite measured by the Griess reaction) in supernatants of neutrophil granulocytes cultured for 24 hours (Figure 4).

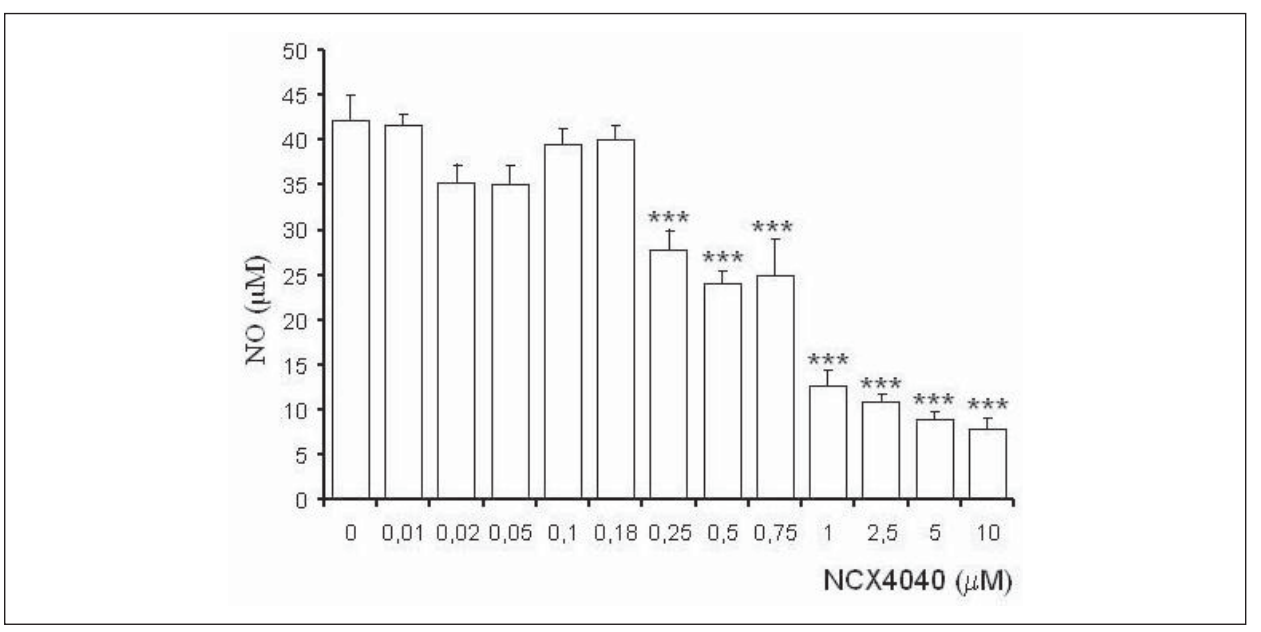

Figure 4. The effect of NCX4040 on the production of nitric oxide by neutrophil granulocytes in $24 \mathrm{~h}$ culture. Production of nitric oxide was measured spectrophotometrically using the Griess method as described in Materials and Methods. Values are given as mean \pm SD of triplicates from one representative experiment, out of several ones with similar results

(*** $p<0.001$ compared to control)

\section{DISCUSSION}

In our previous work we showed that aspirin (in depends of concentration) inhibited and induced apoptosis of rat inflammatory neutrophil granulocytes. The experiment in vitro showed, that aspirin in concentrations from $100 \mu \mathrm{M}$ to $2.5 \mathrm{mM}$ lowered spontaneous apoptosis of neutrophils, but contrary in concentration of $10 \mathrm{mM}$ it promoted apoptosis of these cells (Vasilev et al., 2006). Similar to aspirin, on neutrophil apoptosis acted his nitro derivative NCX4016, but in much lower concentrations. Namely, this nitro-aspirin inhibited apoptosis in concentrations from 1 to $10 \mu \mathrm{M}$, but in concentration of $50 \mu \mathrm{M}$ and higher it induced apoptosis in a dose depend manner (Vasilev et al., 2007).

Herein we demonstrated that new nitro derivative of aspirin, NCX4040, induced apoptosis of rat neutrophil granulocytes in vitro, in very low concentration $(0.25-10 \mu \mathrm{M})$. NCX4040 incubated with these cells at concentration higher than $0.25 \mu \mathrm{M}$ decreased quantity of $\mathrm{NO}$ in neutrophil culture supernatants in a dose dependent manner. It is possible that this observation is related to the induction of apoptosis in neutrophils. Similar results in published literature we could not find. 
There are numerous publications regarding the pro- and anti-apoptotic effect of aspirin on different cell types (Pique et al., 2000; Ricci et al., 2003; Goel et al., 2003), but very few works speak about the effect of aspirin on the apoptosis of neutrophil granulocytes (Garcia-Martinez et al., 2003; Galichs et al., 2004). NCX4040, as well as NCX4016 induces a strong growth-inhibitory effect on various colon (Nath et al., 2003), pancreatic, prostate, lung, and tongue (Kashfi et al., 2002) cancer cell lines. These drugs induce apoptosis of LoVo, LRWZ (Tessei et al., 2005) and other human colon tumor cell lines in vitro (Williams et al., 2001), In vivo, NCX 4040 induced a 40\% reduction in tumor weight (Tessei et al., 2005).

Aspirin is a widely used very effective anti-inflammatory agent, but administration of aspirin is accompanied by an increased risk of gastro-intestinal ulceration and bleeding (Bolla et al., 2006; Hinz and Brune, 2002; Awtry and Loscalzo, 2000; Vane JR et al., 1998). Nitro-aspirins have been synthesized in attempt to reduce the side effects of aspirin in the gastrointestinal tract. (Bolla et al., 2006; Del Soldato et al., 1999). NO-NSAID cause significantly less gastrointestinal damage in experimental animals than NSAID (Muscara et al., 1998). NO-NSAID spare the gastrointestinal tract by means of local release of NO, leading to a local increase of blood flow in the gastric mucosa. NO released from NO-NSAID may also contribute to the anti-inflammatory action of these drugs (Mariotto et al., 1995). NO-aspirins, contrary to aspirin, act gastro protectively, while their anti-inflammatory activity is the same, or even greater than that of aspirin (Burgaud et al., 2002; Bandarage and Janero, 2001; Muscara et al., 1998; Di Napoli and Papa, 2003; Bolla et al., 2006). Nitro-aspirins act through COXinhibition and NO-donation (Bolla et al., 2006). The anti-inflammatory activity of NCX4016 and NCX4040 was confirmed in animal models of pain and inflammation.

Nitro-aspirins combine the biology of NO and acetyl salicylic acid. Unlike the classical NO donors, the new compounds do not produce rapid vasodilatation with the consequent fall of blood pressure typically associated with NO donor administration; these unique properties have been mainly attributed to the slow release of $\mathrm{NO}$ in various body compartments (Chiroli et al., 2003). Nitric oxide (NO) was discovered in 1980 by Furchgott and Zawadzki (Blaise et al, 2005; Moncada et al., 1991). It is a highly reactive, colorless gas with no odor. It is a biochemical messenger both inside the cells and outside, between them, and therefore it possesses many important biochemical and physiological properties. As a signaling molecule, it regulates a broad range of important cellular functions, controls the activation of inflammatory cells and modulates the inflammatory response, and it also influences the process of apoptosis (Bandarage and Janero, 2001; Burgaud, et al., 2002; Hunter, 2002; Napoli and Ignarro, 2000). The first observations that NO modulates apoptosis were published in 1993 (Brune et al., 1999). NO influences the apoptosis of neutrophils (but also other cells), possessing both pro- and anti-apoptotic properties, depending on concentration, but also on the source from which it is derived. There is a multitude of data regarding the proapoptotic effect of $\mathrm{NO}$ on neutrophils and its anti-apoptotic effect on many other cell types. Nitric oxide is key mediator in great number of physiological and pathophysiological processes. It can regulate the rate of 
apoptosis in many cell types including human inflammatory cells. NO has both pro and antiapoptotic properties depending largely on the concentration and flux of $\mathrm{NO}$ and the cell type. Low concentrations of NO (less than $100 \mu \mathrm{M}$ ) (Bogdan et al., 2000) usually have protective effect on cells, whereas higher concentrations derived from inducible isoform of NO synthase drive cell death (Taylor et al., 2003). NO is able both to promote and delay inflammatory cell apoptosis and the mechanisms are still not fully elucidated. Also, NO donation can inhibit Nuclear Factor kB (NF-kB), a transcription factor involved in inflammation. NF-kB regulates the synthesis of cytokines, cytokine receptors and adhesion molecules (Fiorucci et al., 2004).

Neutrophils are highly specialized white blood cells that participate in the host defense against infection (Simon, 2003). These cells are the first line of defense of the innate immune system. Neutrophils are especially important when fighting microorganisms (bacteria and certain fungi) by phagocytosis and releasing toxic mediators. They have a short half-life if they are not recruited to a site of inflammation. Inflammatory mediators, cytokines, growth factors and chemical mediators mediate duration of their life (Ward et al., 1999, Simon, 2003). The tight regulation that governs neutrophils behavior is necessary because the content of neutrophil granules can be noxious to the host tissue (Simon, 2003). In the resolution of inflammation, the accumulated neutrophils need to be safely removed. Apoptosis plays an important role in eliminating such neutrophils from inflamed tissues. Most studies have been performed on purified blood neutrophils aiming to understand the molecular events that control apoptosis in these cells (Simon, 2003). Apoptosis is the physiologic cell death of neutrophils. Number of neutrophils is regulated in vivo by their production in the bone marrow and by apoptosis. Apoptosis at the inflammatory site appears to be delayed when survival factors are generated by pro-inflammatory cytokines (Akgul et al., 2001).

Based on the results of our work, the following may be concluded: NCX4040 induce apoptosis of rat inflammatory neutrophils in vitro in a very low concentration. It is a very important finding which contributes to our knowledge of pharmacological effects of NCX4040.

ACKNOWLEDGMENTS

We thank Dr. Manlio Bolla (Nicox, SA, Nice, France) for providing the NO-NSAID.

Address for correspondence:

Saša Vasilev, Research Associate

Institute for the application of nuclear energy - INEP

Banatska $31 \mathrm{~b}$

11080 Zemun

Serbia

E-mail: svasilev@inep.co.yu

\section{REFERENCES}

1. Akgul C, Moulding DA, Edwards SWI, 2001, Molecular control of neutrophil apoptosis, FEBS letters, 487, 318-22.

2. Awtry EH, Loscalzo J, 2000, Aspirin. Circulation, 101, 1206-18. 
3. Bogdan C, Röllinghoff M,Diefenbach A. 2000, Reactive oxygen and reactive nitrogen intermediates in innate and specific immunity, Curr Opin Immunol, 12, 64-76.

4. Čolić M, Gasić S, Vučević D, Pavicic L, Popovic P, Jandric D, et al. 2000, Modulatory effect of 7-thia8-oxoguanosine on proliferation of rat thymocytes in vitro stimulated with Concanavalin A, Int $J$ Immunopharmacol, 22, 203-12.

5. Ćupić V, 1997, Nesteroidna antiinflamatorna sredstva. Plenarno predavanje po pozivu. Zbornik radova 10. savetovanja veterinara Srbije. Zlatibor, 16-20. septembar.

6. Dlamini Z, Mbita Z, Zungu M, 2004, Genealogy, expression, and molecular mechanisms in apoptosis, Pharmacol Therap, 101, 1-15.

7. Garlichs CD, Eskafi S, Cicha I, Schmeisser A, Walzog B, Raaz D, et al. 2004, Delay of neutrophil apoptosis in acute coronary syndromes, J Leuk Biol, 75, 5, 8 28-35.

8. Garcia-Martinez JM, Fresno Vara JA, Lastres P, Bernabeu C, Betes PO, Martin-Perez J, 2003, Effect of metamizol on promyelocytic and terminaly diferentiated granulocytic cells: comparative analysis with acetylsalicylic acid and diclofenac, Biochem Pharmacol, 65, 209-17.

9. Girard $D, 2003$, Activation of human polymorphonuclear neutrophils by environmental contaminants, Rev Environ Health, 18, 2, 77-93.

10. Goel A, Chang DK, Ricciardiello L, Gasche C, Boland CR, 2003, A novel mechanism for aspirinmediated growth inhibition of human colon cancer cells, Clin Canc Res, 9, 383-90.

11. Green LC, Wagner DA, Glogowski J, Skipper PL, Wishnok JS, Tannenbaum SR, 1982, Analysis of nitrate, nitrite and (15N) nitrate in biological fluids, Anal biochem, 126, 131-8.

12. Guimaraes CA, Linden R, 2004, Programed cell death, Eur J Biochem, 271, 1638-50.

13. Hinz B, Brune K, 2002, Cyclooxigenase-2 - 10 years later, J Pharmacol Exp Therap. 300, 367-75.

14. Kam PCA, Ferch NI, 2000, Apoptosis: mechanisms and clinical implications, Anaesthesia, 55, 1081-93.

15. Maianski NA, Maianski AN, Kuijpers TW, Roos D, 2004, Apoptosis of neutrophils, Acta Haematol, 111, 56-66.

16. Middleton MM, Campbell PA, 1989, Functions of purified mouse neutrophils isolated from gelatin sponges, J Leuk Biol, 46, 461-6.

17. Migita K, Eguchi K, Kawabe Y, Mizokami A, Tsukada T, Nagataki S, 1994, Prevention of anti-CD3 monoclonal antibody-induced thymic apoptosis by protein tyrosine kinase inhibitors. $J$ Immunol,153, 8, 3457-65.

18. Pique M, Barragan M, Dalmau M, Bellosillo B, Pons G, Gil J, 2000, Aspirin induces apoptosis through mitochondrial cytohrome c release, FEBS Letters, 480, 193-6.

19. Porter SN, Howarth GS, Butler RN, 2000, Non-steroidal anti-inflammatory grugs and apoptosis in the gastrointestinal tract: potential role of the pentose phosphate pathways, Eur J Pharmacol, 397, 1-9.

20. Ricchi P, Palma AD, Matola TD, Apicella A, Fortunato R, Zarrilli $R$ et al. 2003, Aspirin protects caco-2 cells from apoptosis after serum deprivation through the activation of a phosphatidylinositol 3 kinase / AKT/p21 /Cip/waf1 pathway, Mol Pharmacol, 64, 407-14.

21. Simon $H U, 2003$, Neutrophil apoptosis pathway and their modifications in inflammation, Immunol Rev, 193, 101-10.

22. Taylor EL, Megson IL, Haslett C, Rossi AG, 2003, Nitric oxide: a key regulator of myeloid inflammatory cell apoptosis, Cell Death Differen, 10, 418-30.

23. Tegeder I, Pfeilschifter J, Geisslinger G, 2001, Cyclooxygenase - independent actions of cxclooxygenase inhibitors, FASEB J, 15, 2057-72.

24. Thun MJ, 1997, Aspirin and gastrointestinal cancer, Adv Exp Med Biol, 400A, 395-402.

25. Vane JR, Bakhle YS, Botting RM, 1998, Cyclooxigenases 1 and 2, Ann Rev Pharmacol Toxicol, 38, 97-120.

26. Ward C, Dransfield I, Chilvers ER, Haslett C, Rossi AG, 1999, Pharmacological manipulation of granulocyte apoptosis: potential therapeutic targets, Trends Pharmacol Sci, 20, 503-9.

27. Vermes I, Haanen C, Reutelingsperger C, 2000, Flow cytometry of apoptotic cell death, J Immunol Meth, 243,167-90. 
Acta Veterinaria (Beograd), Vol. 58. No. 5-6, 449-457, 2008.

Vasilev $S$ et al:: The effect of a new nitro-aspirin on

apoptosis of neutrophil granulocytes

28. Witko-Sarsat V, Rieu P, Descamps-Latscha B, Lesavre P, Halbwachs-Mecarelli L, 2000, Neutrophils: molecules, functions and pathophysiological aspects, Lab Invest, 80, 5, 617.

EFEKAT NOVOG NITRO-ASPIRINA NA APOPTOZU NEUTROFILNIH GRANULOCITA

VASILEV S, VUČEVIĆ DRAGANA, GAŠIĆ SONJA, MAJSTOROVIĆ IVANA, VASILIJIĆ S, ĆUPIĆ V i ČOLIĆ M

SADRŽAJ

Neutrofilni granulociti su deo imunog sistema, uključeni u odbranu organizma od mikroorganizama. Oni imaju najkraći životni vek među leukocitima, koji se može modulisati citokinima i farmakološkim agensima. Efekat novog derivata aspirina, NCX4040, na apoptozu inflamatornih granulocita do sada nije ispitivan. Zbog toga smo u ovom radu ispitivali efekat nitro-aspirina (NCX4040) na apoptozu inflamatornih neutrofilnih granulocita pacova. Inflamatorni granulociti su izolovani iz polivinilskih sunđera implantiranih potkožno pacovima Albino Oxford (AO) soja. Inflamatorne ćelije koje su izolovane 20 sati kasnije, najvećim delom (više od $95 \%$ ) su bili neutrofilni granulociti. Ove ćelije su kultivisane 24 sata sa NCX4040 u koncentracijama od $0.01 \mu \mathrm{M}$ do $10 \mu \mathrm{M}$. Supernatanti kultura neutrofila su sakupljani, i korišćeni za merenje koncentracije NO. Ćelije su bojene propidijum jodidom i apoptoza je analizirana na protočnom citofluorimetru, kao i pomoću morfoloških kriterijuma. Ustanovili smo da u koncentracijama od $0.25 \mu \mathrm{M}$ do 10 $\mu \mathrm{M}$ ovaj nitro-aspirin indukuje, na dozno zavisan način, apoptozu neutrofilnih granulocita. Apoptoza indukovana nitro-aspirinom je bila u pozitivnoj korelaciji sa smanjenom produkcijom NO. 